\title{
Identification of Optimal Target Gene Regions for Hepatitis B Virus Genotyping by DNA Sequencing
}

\author{
Wafa Habbal $^{a}$ Barbara Christine Gärtner ${ }^{b} \quad$ Fawza Monem ${ }^{a}$

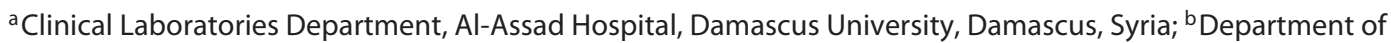 \\ Microbiology and Hygiene, University of Saarland Medical School, Homburg/Saar, Germany
}

\section{Key Words}

Hepatitis B virus genotyping - DNA sequencing · Target gene region - Reference genotypes - NCBI genotyping tool · Referential genotyping guide

\begin{abstract}
Objectives: DNA sequencing is the gold standard for hepatitis B virus (HBV) genotyping. We investigated the intergenotypic discriminatory capabilities of various target gene regions over the entire HBV genome, introducing a novel data evaluation approach generally applicable in viral genotyping. Methods: Complete genome sequences of seventy HBV variants obtained from the sera of 50 Syrian patients were determined and assigned GenBank accession No. from JN257148 to JN257217. Nucleotide sequence contigs were analyzed together with the NCBI reference genome set of $\mathrm{HBV}$ genotypes. Nine target gene regions were analyzed by phylogenetic and scored BLAST analyses. Thirty-one overlapping 300-bp sequence segments over the entire genome were also analyzed using a scored BLAST analysis, and intergenotypic discriminatory capabilities were statistically estimated for each. Results: Intergenotype discrimination was extremely significant when targeting either the complete genome, the entire coding sequence of either $\mathrm{P}$ or $\mathrm{S}$ genes,
\end{abstract}

or any 300-bp sequence segment over the coding sequences of $\mathrm{S}$ protein or the polymerase $\mathrm{N}$-terminal domain. Interestingly, intergenotypic discriminatory capability correlated negatively with intragenotype variation. Conclusions: The intragenotypic conservation of certain target gene regions determines the intergenotypic discriminatory capability and allows reliable genotyping with relatively short segments. Our referential genome-wide tabulated guide allows for selecting candidate target gene regions for sequencing-based HBV genotyping.

(c) 2013 S. Karger AG, Basel

\section{Introduction}

Hepatitis B virus (HBV) infection is highly prevalent worldwide, characterized by high infection and mortality rates, and hence considered one of the major public health issues. Chronically infected patients are at high risk of developing hepatic cirrhosis and hepatocellular carcinoma $[1,2] . \mathrm{HBV}$ is a DNA virus with a circular partially double-stranded 3.2-kb genome [3]. At least eight HBV genotypes (A through $\mathrm{H}$ ) have been identified based on genome-wide intergenotypic diversity [4]. Their occurrence is associated with ethnic origins and geographical

\section{KARGER}

E-Mail karger@karger.com

www.karger.com/int
(C) 2013 S. Karger AG, Basel

$0300-5526 / 13 / 0565-0325 \$ 38.00 / 0$
Wafa Habbal, B Pharm, PhD, CPHQ

Clinical Laboratories Department, Al-Assad Hospital, Damascus University PO Box 10769

Damascus (Syria)

E-Mailwafahabbal@hotmail.com 
regions, and gives rise to various clinical outcomes, such as response to antiviral therapy, liver disease progression, mutant selection $[5,6]$ and vaccine effectiveness [7]. HBV genotyping, therefore, has become a valuable tool both epidemiologically towards tracing the infection routes and clinically in relation to patient management and therapeutic decisions $[8,9]$.

Among several molecular techniques described for $\mathrm{HBV}$ genotyping, DNA sequencing is the gold standard $[1,2,10,11]$ recommended to resolve result discordance [2] and detect recombinant genotypes [5]. To date, diverse target gene regions for HBV genotyping by DNA sequencing have been reported, such as the entire genome $[6,11]$, the $S$ gene overlapping the reverse transcriptase region of the $P$ gene $[1,4,12]$ or the pre-S region $[2,13-15]$. There is no consensus regarding the most suitable target region [2], and no comprehensive systematic research has been conducted to explore the optimum target gene regions over the entire viral genome. Our study aimed at investigating the intergenotypic discriminatory capabilities of various target gene regions over the entire genome of reference and clinical HBV sequences utilizing a novel data evaluation approach.

\section{Materials and Methods}

\section{Specimens}

Serum samples from 50 Syrian hepatitis B patients were drawn between August 2008 and April 2010. Only samples with HBV DNA concentrations $\geq 6 \log$ copies/ml were included to increase the sensitivity of detecting various HBV variants in mixed virus populations. Written informed consent was obtained from all enrolled patients. Viral DNA was extracted from $200 \mu \mathrm{l}$ serum using the High Pure Viral Nucleic Acid Kit (Roche Diagnostics, Germany), and $50-\mu \mathrm{l}$-volume DNA extracts were kept at $-80^{\circ}$ for further testing.

\section{Complete HBV Genome Sequencing}

PCR and cycle sequencing reactions included up to 32-fold degeneracy primers (TIB MOLBIOL, Germany; table 1) matching all reference HBV genotypes as predefined by the NCBI Genotyping resource [16-18]. Three overlapping 1.2- to 1.7-kb-long PCR fragments were amplified each in a $50-\mu \mathrm{l}$-volume reaction containing $1 \mu \mathrm{M}$ of each primer, $1.5 \mathrm{mM}$ of $\mathrm{MgCl}_{2}$ and $5 \mu \mathrm{l}$ of extracted DNA using GeneAmp High Fidelity PCR System (Applied Biosystems, USA). Thermal cycling was initiated at $94^{\circ}$ for 2 min followed by 40 cycles of denaturation at $94^{\circ}$ for $15 \mathrm{~s}$, annealing at $55^{\circ}$ for $30 \mathrm{~s}$ and extension at $72^{\circ}$ for $3 \mathrm{~min}$. An additional extension time of $5 \mathrm{~s}$ per cycle after cycle 10 , and a final extension step at $72^{\circ}$ for 7 min were added. PCR products were directly sequenced using the BigDye ${ }^{\circledR}$ Terminator v3.1 Cycle Sequencing Kit on the ABI PRISM $^{\circledR}$ 3100-Avant ${ }^{\mathrm{TM}}$ Genetic Analyzer (Applied Biosystems, USA). Sequence ambiguities due to quasispecies variation were resolved by DNA cloning using the TOPO TA Cloning Kit (Invitro- gen, USA) and up to eight clones were analyzed. Nucleotide sequence contigs were assigned seventy GenBank accession No. from JN257148 to JN257217, and were further analyzed together with the NCBI reference genome set of HBV genotypes.

\section{Phylogenetic Analysis}

Ninety-four reference and clinical HBV genomes were aligned using ClustalW2 $[19,20]$. The phylogenetic analysis was carried out by bayesian inference of phylogeny using the general timereversible evolutionary model with a gamma-distributed rate variation across the sites and a proportion of invariable sites. Nine phylogenetic trees of various target gene regions including the complete genome and seven coding sequences (CDS) of the viral genes (P gene, polymerase CDS; $\mathrm{S}$ gene, large $\mathrm{S}$, middle $\mathrm{S}$ and $\mathrm{S}$ protein CDS in addition to pre-S; $\mathrm{X}$ gene, $\mathrm{X}$ protein CDS; $\mathrm{C}$ gene, precore/core and core protein CDS) were separately constructed using MrBayes v3.1.2 [21, 22], and then displayed using TreeView [23].

\section{Sequence Segment Analysis}

Ninety-three reference and clinical HBV genomes were subtyped using the NCBI Genotyping tool [16]. Nine query sequences of various target gene regions each, including complete genome and seven viral CDS in addition to pre-S region, were compared to the predefined reference set based on scored BLAST pairwise alignments. Likewise, similarity scores of 31 overlapping 300-bp sequence segments with 100-bp incremental steps along the entire genome of each query sequence were imported into spread sheets for further analysis. The unpaired Student's t test was used to determine whether the intra- and intergenotypic similarity score means were significantly different in a dual genotype matrix; the difference was considered extremely significant when $p<0.001$, very significant when $0.001<\mathrm{p}<0.01$, and significant when 0.01 $<\mathrm{p}<0.05$. The $\mathrm{p}$ value was adopted for ranking sequence segments in terms of intergenotypic discriminatory capability. In addition, the relative standard deviation (RSD) of intragenotypic similarity scores was used to estimate intragenotype variation. Pearson's correlation coefficients between Student's t test $p$ values and RSDs were finally calculated.

\section{Results}

\section{Phylogenetic Analysis}

All nine phylogenetic trees exhibited common topological characteristics where genotype-specific reference sequences clustered in monophyletic clades discriminating all HBV genotypes, while all sequences from Syrian isolates clustered in the genotype D clade (fig. 1a). Exceptions were confined to phylogenetic trees of $\mathrm{C}$ and $\mathrm{X}$ gene CDS showing poor discrimination and/or misclassification of reference genotypes B and/or D, respectively. Figure $1 \mathrm{~b}$ shows that the $\mathrm{C}$ gene $\mathrm{CDS}$ of reference genotypes $\mathrm{E}$ and $\mathrm{D}$ were not discriminated in distinct clades but rather clustered together in one clade, while those of reference genotype B appeared separately as sister groups 
Table 1. Primers used for complete HBV genome sequencing

\begin{tabular}{|c|c|c|c|}
\hline Primer $^{\mathrm{a}}$ & $5^{\prime}-3^{\prime}$ sequence & Degeneracy $^{\mathrm{b}}$ & Annealing site ${ }^{c}$ \\
\hline \multicolumn{4}{|c|}{ PCR and cycle sequencing primers } \\
\hline F1 & GGG TCA CCW TAT WCY TGG GAA & 8 -fold & $2814-2834$ \\
\hline $\mathrm{R} 1$ & CGT TGC CKR GCA ACS GGG TAA AGG & 8 -fold & $1163-1140$ \\
\hline $\mathrm{F} 2$ & GTT TCT CYT GGC TCA GTT TA & 2 -fold & $660-679$ \\
\hline $\mathrm{R} 2$ & AAA AAG TYR CAT GRT GMT GG & 16-fold & $1825-1806$ \\
\hline F3 & ACR THG CAT GGA GAC CAC CG & 6-fold & $1601-1620$ \\
\hline R3 & GAA CTG GAG CCA CCA GCA GG & 1 -fold & $75-56$ \\
\hline $\mathrm{F} 4^{\mathrm{d}}$ & TTT TTC MCC TCT GCC TAD TCA & 6-fold & $1821-1841$ \\
\hline $\mathrm{R} 4^{\mathrm{d}}$ & CCC TAG AAA ATT GAG AGA AGT C & 1 -fold & $283-262$ \\
\hline \multicolumn{4}{|c|}{ Cycle sequencing primers } \\
\hline F5 & GTC TAG ACT CGT GGT GGA CTT CTC & 1-fold & $246-269$ \\
\hline F6 & YTG GCC WAA ATT CGC RRT C & 16-fold & $300-318$ \\
\hline $\mathrm{R} 5$ & GAA GAT GAG GCA TAG CAG CAG G & 1-fold & $433-412$ \\
\hline R6 & AAG CCA RAC AGT GGG GGA AAG C & 2-fold & $730-709$ \\
\hline F7 & CCC CAC TGT YTG GCT TTY AG & 4-fold & $715-734$ \\
\hline R7_1 & TTC KYT GMC ASA CYT TCC A & 32-fold & $997-979$ \\
\hline R7_2 & TAC KYT GMC ASA CYT TCC A & 32-fold & $997-979$ \\
\hline $\mathrm{F} 8$ & YTC GYC AAC BTA YAA GGC CTT T & 24-fold & $1098-1119$ \\
\hline F9 & GCT GAY GCA ACC CCC ACK GG & 4-fold & $1186-1205$ \\
\hline F10 & CTC TGC CGA TCC ATA CTG CGG AA & 1 -fold & $1256-1278$ \\
\hline $\mathrm{R} 8$ & GAT TCA GCG CYG AYG GGA CGT A & 4-fold & $1447-1426$ \\
\hline F11_1 & TCA GRC AAG CHA TYY TCT GCT GG & 24-fold & $2064-2086$ \\
\hline F11_2 & TCA GRC AAG CHA TYY TTT GCT GG & 24-fold & $2064-2086$ \\
\hline F11_3 & TCA GRC AAG CHA TYY TGT GCT GG & 24-fold & $2064-2086$ \\
\hline $\mathrm{R} 9$ & GTK GAT ARG ATA GGG GCA TTT GRT GG & 8-fold & $2325-2300$ \\
\hline $\mathrm{R} 10$ & KSA GWT CTK CKG CGA CGC GGC & 32-fold & $2430-2410$ \\
\hline F12_1 & AAG GTG GGR AAY TTY ACS GGK C & 32-fold & $2469-2490$ \\
\hline F12_2 & AAG GTG GGR AAY TTY ACT GGK C & 16-fold & $2469-2490$ \\
\hline $\mathrm{F} 13^{-}$ & GCH TCA TTT TGY GGG TCA CCW TA & 12-fold & $2802-2824$ \\
\hline $\mathrm{R} 11$ & CAT GMY GTA GHT CTT GTT CC & 12-fold & $2850-2831$ \\
\hline F14 & YTG GGR TGG AGC CCT CAR KCW & 32-fold & $3070-3090$ \\
\hline F15 & CCT CCY GYY TCY RCC AAT CG & 32-fold & $3124-3143$ \\
\hline
\end{tabular}

\footnotetext{
a Primers coded $(\mathrm{F}=$ forward primer; $\mathrm{R}$ = reverse primer).

${ }^{\mathrm{b}}$ Degeneracy fold equals the number of primers included in an equimolar mixture, computed by multiplying the numbers of bases represented by the degenerate base symbols, e.g., F1: GGG TCA CC[A/T] TAT [A/T]C[C/T] TGG GAA has $2 \times 2 \times 2=8$-fold degeneracy.

${ }^{c}$ Nucleotide number according to GenBank accession No. NC_003977.

d An alternative PCR fragment was amplified when F3 and R3 failed to generate the third amplicon.
}

either to genotype $\mathrm{C}$ or to genotypes $\mathrm{A}, \mathrm{D}$ and $\mathrm{E}$. Moreover, one reference $\mathrm{X}$ gene CDS of genotype $\mathrm{D}$ was misplaced to the genotype A clade (fig. 1c).

\section{Sequence Segment Analysis of Reference Genotypes}

Average intra- and intergenotypic similarity scores between reference sequences were extremely significantly different among most genotype target regions. Exceptions were observed in $\mathrm{C}$ and $\mathrm{X}$ gene $\mathrm{CDS}$ regions of genotypes $\mathrm{B}$ and/or $\mathrm{D}$, respectively, versus reference geno- types A, C and/or E showing concurrently the highest intragenotypic variation in terms of RSD values (in \%) of all genotypes (table 2).

Intergenotype discrimination was extremely significant over 13 of 31 (42\%) genome-wide 300-bp sequence segments including segments $2-6$ of $S$ gene CDS and segments 24-31 of $P$ gene sequences coding for the N-terminal domain. However, the remaining segment 1 of preS2/S sequences, segments 7-14 of $\mathrm{P}$ gene sequences coding for reverse transcriptase-like and C-terminal domains, 


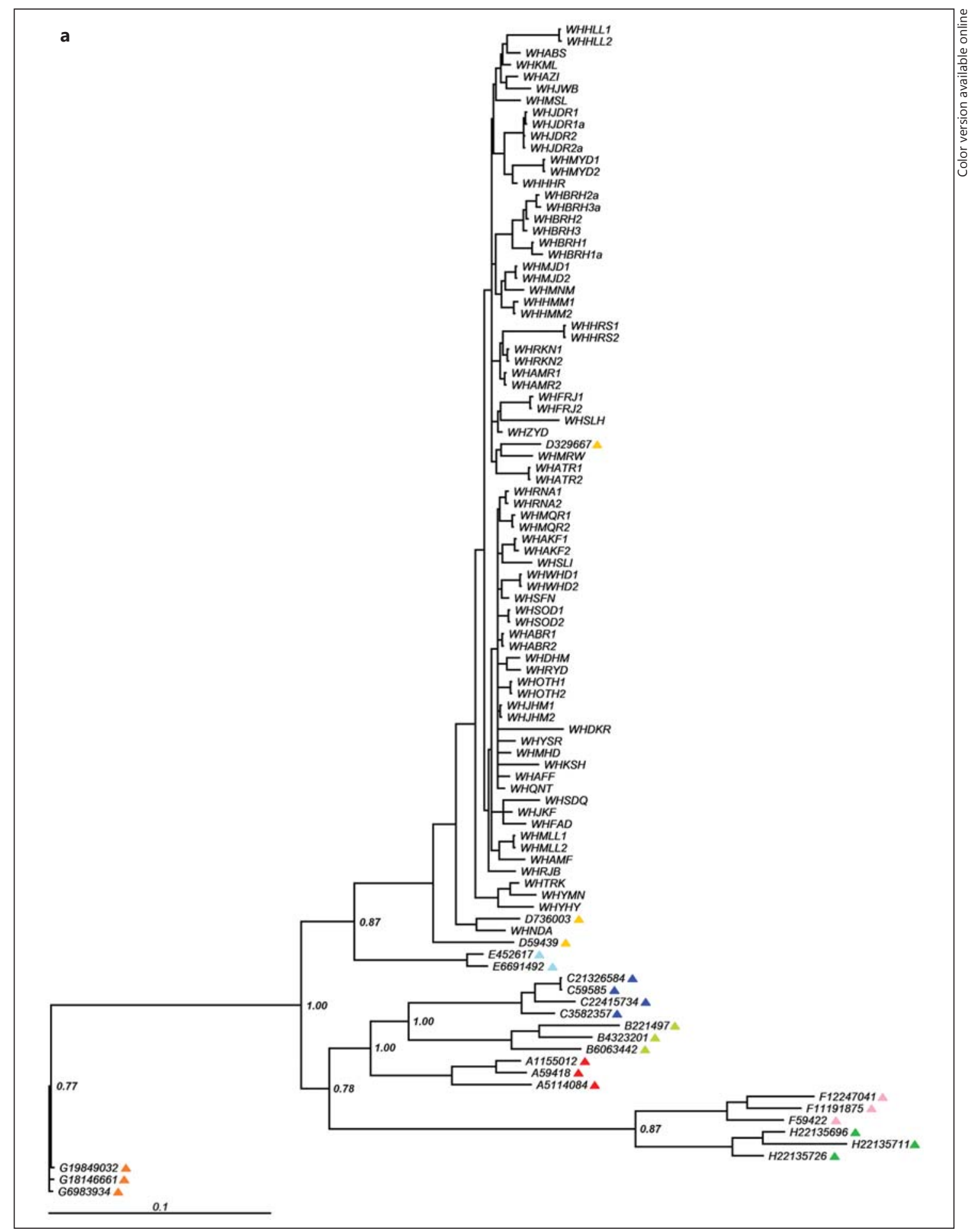

Fig. 1. a Unrooted phylogenetic tree of HBV complete genome, including both reference and clinical sequences, constructed by Bayesian inference of phylogeny of MrBayes v3.1.2 using the general time reversible evolutionary model with a gamma-distributed rate variation across the sites and a proportion of invariable sites. This phylogenetic tree (as well as polymerase, large S, middle $S$, and S CDS; data not shown) discriminates all reference HBV genotypes in monophyletic clades. All 70 clinical HBV isolates from enrolled Syrian patients clustered in reference genotype D clade and are prefixed by 'WH', while names of the $24 \mathrm{HBV}$ reference sequences are prefixed by the genotype followed by the GenInfo Identifier (GI) and a color-coded triangle. Posterior probabilities are shown for each split of genotype-specific monophyletic clades. 


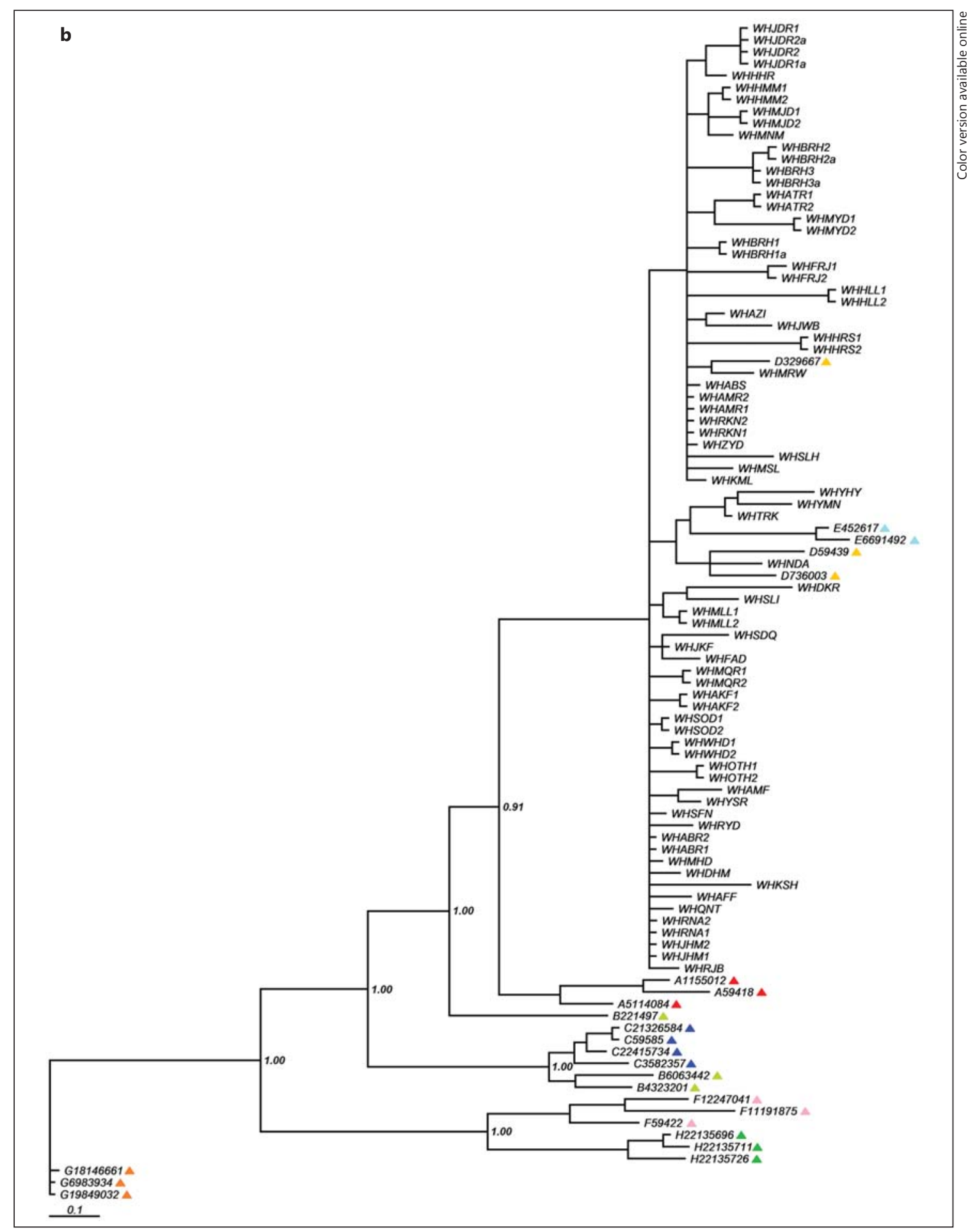

Fig. 1. b Unrooted phylogenetic tree of HBV core gene, including both reference and clinical sequences, constructed by Bayesian inference of phylogeny of MrBayes v3.1.2 using the general time reversible evolutionary model with a gamma-distributed rate variation across the sites and a proportion of invariable sites. This phylogenetic tree shows poor discrimination and misclassification of some reference genotypes. All 70 clinical HBV isolates from en- rolled Syrian patients clustered in reference genotype D clade and are prefixed by 'WH', while names of the $24 \mathrm{HBV}$ reference sequences are prefixed by the genotype followed by the GenInfo Identifier (GI) and a color-coded triangle. Posterior probabilities are shown for each split of genotype-specific monophyletic clades. 


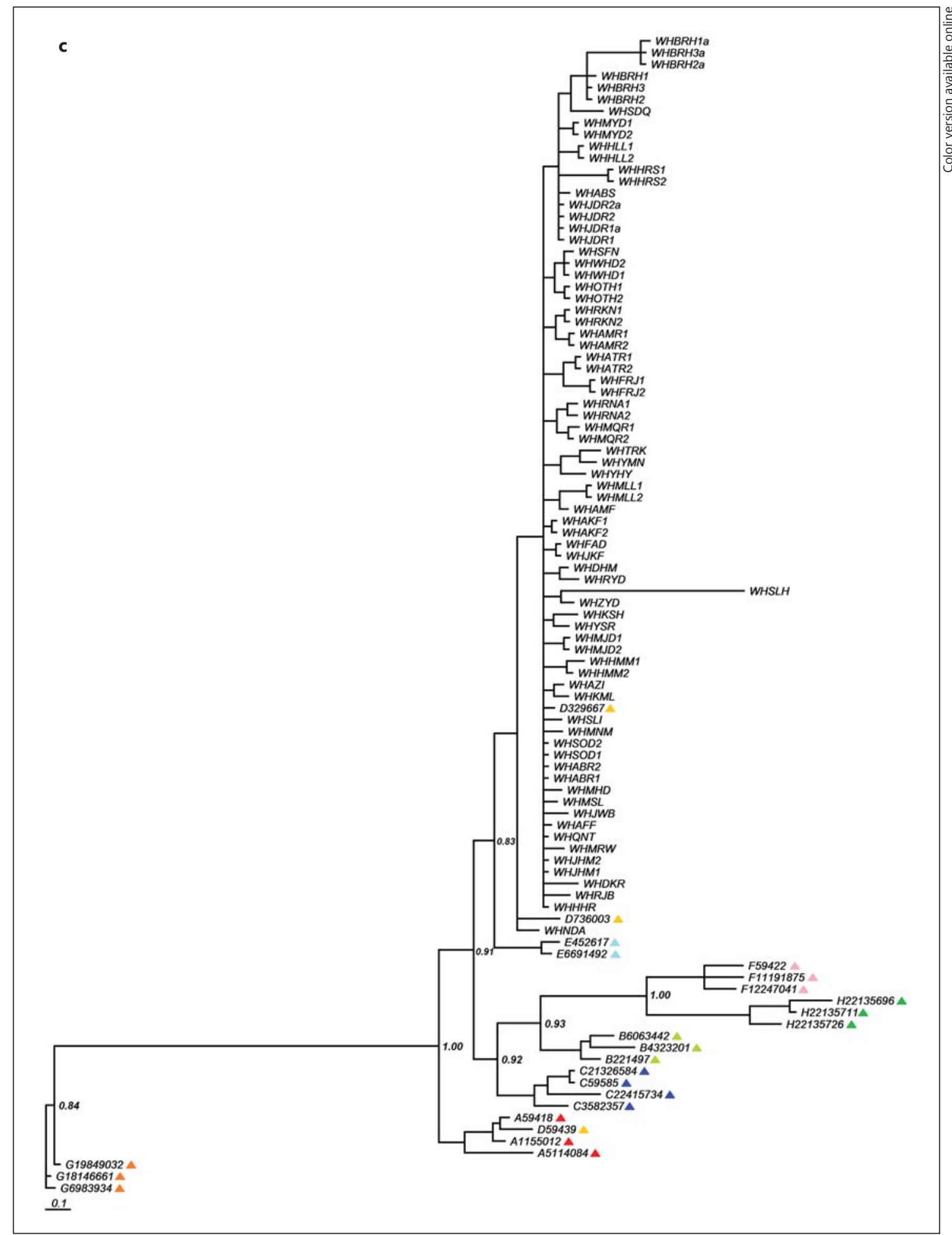

Fig. 1. c Unrooted phylogenetic tree of HBV X gene, including both reference and clinical sequences, constructed by Bayesian inference of phylogeny of MrBayes v3.1.2 using the general time reversible evolutionary model with a gamma-distributed rate variation across the sites and a proportion of invariable sites. This phylogenetic tree shows misclassification of reference genotype D. All
70 clinical HBV isolates from enrolled Syrian patients clustered in reference genotype $\mathrm{D}$ clade and are prefixed by ' $\mathrm{WH}$ ', while names of the $24 \mathrm{HBV}$ reference sequences are prefixed by the genotype followed by the GenInfo Identifier (GI) and a color-coded triangle. Posterior probabilities are shown for each split of genotype-specific monophyletic clades. 
Table 2. Intergenotype discrimination and intragenotype variation of hepatitis B virus reference genotypes over various target gene regions $^{\mathrm{a}}$

\begin{tabular}{|c|c|c|c|c|c|c|c|c|c|c|}
\hline \multirow{2}{*}{$\begin{array}{l}\text { Target } \\
\text { region }\end{array}$} & \multirow{2}{*}{$\begin{array}{l}\text { HBV } \\
\text { genotype }\end{array}$} & \multicolumn{8}{|c|}{ Intergenotypic discrimination $^{b}$} & \multirow{2}{*}{$\begin{array}{l}\text { Intra- } \\
\text { genotypic } \\
\text { variation }\end{array}$} \\
\hline & & A & B & C & $\mathrm{D}$ & E & $\mathrm{F}$ & G & $\mathrm{H}$ & \\
\hline \multirow{9}{*}{ 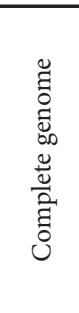 } & $\mathrm{A}$ & NA & ES & $\overline{E S}$ & ES & ES & $\mathrm{ES}$ & ES & ES & $4 \%$ \\
\hline & $\bar{B}$ & ES & NA & ES & ES & ES & ES & ES & ES & $3 \%$ \\
\hline & $\mathrm{C}$ & ES & ES & NA & ES & ES & ES & ES & ES & $2 \%$ \\
\hline & $\mathrm{D}$ & ES & ES & ES & NA & ES & ES & ES & ES & $4 \%$ \\
\hline & D (our study) & ES & ES & ES & NA & ES & ES & ES & ES & $5 \%$ \\
\hline & $\mathrm{E}$ & ES & ES & ES & ES & NA & ES & ES & ES & NA \\
\hline & $\mathrm{F}$ & ES & ES & ES & ES & ES & NA & ES & ES & $5 \%$ \\
\hline & $\mathrm{G}$ & ES & ES & ES & ES & ES & ES & NA & ES & $0 \%$ \\
\hline & $\mathrm{H}$ & ES & ES & ES & ES & ES & ES & ES & NA & $1 \%$ \\
\hline \multirow{9}{*}{ 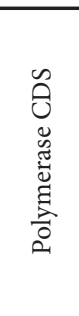 } & $\mathrm{A}$ & NA & ES & ES & ES & ES & ES & ES & ES & $8 \%$ \\
\hline & $\mathrm{B}$ & ES & NA & ES & ES & ES & ES & ES & ES & $4 \%$ \\
\hline & $\mathrm{C}$ & ES & ES & NA & ES & ES & ES & ES & ES & $1 \%$ \\
\hline & $\mathrm{D}$ & ES & ES & ES & NA & ES & ES & ES & ES & $3 \%$ \\
\hline & D (our study) & ES & ES & ES & NA & ES & ES & ES & ES & $5 \%$ \\
\hline & E & ES & ES & ES & ES & NA & ES & ES & ES & NA \\
\hline & $\mathrm{F}$ & ES & ES & ES & ES & ES & NA & ES & ES & $1 \%$ \\
\hline & G & ES & ES & ES & ES & ES & ES & NA & ES & $0 \%$ \\
\hline & $\mathrm{H}$ & ES & ES & ES & ES & ES & ES & ES & $\mathrm{NA}$ & $3 \%$ \\
\hline \multirow{9}{*}{ 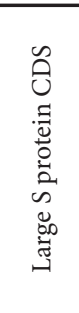 } & $\mathrm{A}$ & $\mathrm{NA}$ & ES & ES & ES & ES & ES & ES & ES & $4 \%$ \\
\hline & B & ES & $\mathrm{NA}$ & ES & ES & ES & ES & ES & ES & $3 \%$ \\
\hline & C & ES & ES & NA & ES & ES & ES & ES & ES & $0 \%$ \\
\hline & $\mathrm{D}$ & ES & ES & ES & NA & ES & ES & ES & ES & $0 \%$ \\
\hline & D (our study) & ES & ES & ES & NA & ES & ES & ES & ES & $3 \%$ \\
\hline & E & ES & ES & ES & ES & NA & ES & ES & ES & NA \\
\hline & F & ES & ES & ES & ES & ES & $\mathrm{NA}$ & ES & ES & $1 \%$ \\
\hline & G & ES & ES & ES & ES & ES & ES & NA & ES & $0 \%$ \\
\hline & $\mathrm{H}$ & ES & ES & ES & ES & ES & ES & ES & $\mathrm{NA}$ & $1 \%$ \\
\hline \multirow{9}{*}{ 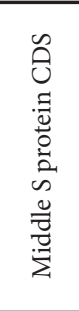 } & $\mathrm{A}$ & NA & $\overline{E S}$ & ES & ES & ES & ES & ES & ES & $2 \%$ \\
\hline & B & ES & $\mathrm{NA}$ & ES & ES & ES & ES & ES & ES & $2 \%$ \\
\hline & $\mathrm{C}$ & ES & ES & NA & ES & ES & ES & ES & ES & $3 \%$ \\
\hline & \begin{tabular}{|l|l}
$\mathrm{D}$ \\
\end{tabular} & ES & ES & ES & NA & ES & ES & ES & ES & $1 \%$ \\
\hline & D (our study) & ES & ES & ES & NA & ES & ES & ES & ES & $2 \%$ \\
\hline & E & ES & ES & ES & ES & NA & ES & ES & ES & NA \\
\hline & $\mathrm{F}$ & ES & ES & ES & ES & ES & NA & ES & ES & $1 \%$ \\
\hline & G & ES & ES & ES & ES & ES & ES & NA & ES & $0 \%$ \\
\hline & $\mathrm{H}$ & ES & ES & ES & ES & ES & ES & ES & NA & $1 \%$ \\
\hline \multirow{9}{*}{ 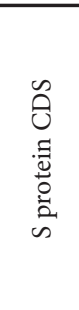 } & $\mathrm{A}$ & NA & $\overline{E S}$ & ES & ES & ES & ES & ES & ES & $1 \%$ \\
\hline & $\mathrm{B}$ & ES & NA & ES & ES & ES & ES & ES & ES & $1 \%$ \\
\hline & C & ES & ES & NA & ES & ES & ES & ES & ES & $1 \%$ \\
\hline & $\mathrm{D}$ & ES & ES & ES & NA & ES & ES & ES & ES & $1 \%$ \\
\hline & D (our study) & ES & ES & ES & NA & ES & ES & ES & ES & $2 \%$ \\
\hline & E & ES & ES & ES & ES & NA & ES & ES & ES & NA \\
\hline & $\mathrm{F}$ & ES & ES & ES & ES & ES & NA & ES & ES & $2 \%$ \\
\hline & G & ES & ES & ES & ES & ES & ES & NA & ES & $0 \%$ \\
\hline & $\mathrm{H}$ & ES & ES & ES & ES & ES & ES & ES & NA & $1 \%$ \\
\hline
\end{tabular}

\begin{tabular}{|c|c|c|c|c|c|c|c|c|c|c|}
\hline \multirow{2}{*}{$\begin{array}{l}\text { Target } \\
\text { region }\end{array}$} & \multirow{2}{*}{$\begin{array}{l}\text { HBV } \\
\text { genotype }\end{array}$} & \multicolumn{8}{|c|}{ Intergenotypic discrimination ${ }^{b}$} & \multirow{2}{*}{$\begin{array}{l}\text { Intra- } \\
\text { genotypic } \\
\text { variation }\end{array}$} \\
\hline & & A & B & C & $\mathrm{D}$ & E & F & G & $\mathrm{H}$ & \\
\hline \multirow{9}{*}{ 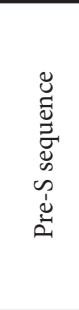 } & A & NA & ES & ES & ES & ES & ES & ES & ES & $9 \%$ \\
\hline & $\mathrm{B}$ & ES & NA & ES & ES & ES & ES & ES & ES & $7 \%$ \\
\hline & C & ES & ES & NA & ES & ES & ES & ES & ES & $8 \%$ \\
\hline & $\mathrm{D}$ & ES & ES & ES & NA & ES & ES & ES & ES & $3 \%$ \\
\hline & D (our study) & ES & ES & ES & NA & ES & ES & ES & ES & $11 \%$ \\
\hline & E & VS & ES & ES & ES & $\mathrm{NA}$ & ES & ES & ES & NA \\
\hline & $\mathrm{F}$ & ES & ES & ES & ES & ES & NA & ES & ES & $3 \%$ \\
\hline & G & ES & ES & ES & ES & ES & ES & NA & ES & $0 \%$ \\
\hline & $\mathrm{H}$ & ES & ES & ES & ES & ES & ES & ES & NA & $2 \%$ \\
\hline \multirow{9}{*}{ 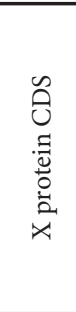 } & $\mathrm{A}$ & $\mathrm{NA}$ & ES & ES & $S$ & ES & ES & ES & ES & $6 \%$ \\
\hline & B & ES & NA & ES & ES & ES & ES & ES & ES & $2 \%$ \\
\hline & C & ES & ES & NA & ES & ES & ES & ES & ES & $3 \%$ \\
\hline & $\mathrm{D}$ & NS & $S$ & NS & NA & NS & ES & ES & ES & $9 \%$ \\
\hline & D (our study) & ES & ES & ES & NA & NS & ES & ES & ES & $11 \%$ \\
\hline & $\mathrm{E}$ & ES & ES & ES & VS & $\mathrm{NA}$ & ES & ES & ES & NA \\
\hline & $\mathrm{F}$ & ES & ES & ES & ES & ES & NA & ES & ES & $0 \%$ \\
\hline & $\mathrm{G}$ & ES & ES & ES & ES & ES & ES & NA & ES & $1 \%$ \\
\hline & $\mathrm{H}$ & ES & ES & ES & ES & ES & ES & ES & NA & $6 \%$ \\
\hline \multirow{9}{*}{ 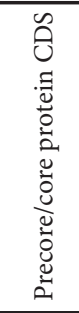 } & $\mathrm{A}$ & $\mathrm{NA}$ & ES & ES & ES & ES & ES & ES & ES & $5 \%$ \\
\hline & B & NS & NA & NS & $S$ & NS & ES & VS & ES & $19 \%$ \\
\hline & C & ES & S & NA & ES & ES & ES & ES & ES & $2 \%$ \\
\hline & $\mathrm{D}$ & ES & ES & ES & NA & S & ES & ES & ES & $4 \%$ \\
\hline & D (our study) & ES & ES & ES & NA & VS & ES & ES & ES & $11 \%$ \\
\hline & $\mathrm{E}$ & ES & ES & ES & ES & NA & ES & ES & ES & NA \\
\hline & $\mathrm{F}$ & ES & ES & ES & ES & ES & NA & ES & ES & $2 \%$ \\
\hline & $\mathrm{G}$ & ES & ES & ES & ES & ES & ES & NA & ES & $0 \%$ \\
\hline & $\mathrm{H}$ & ES & ES & ES & ES & ES & ES & ES & NA & $5 \%$ \\
\hline \multirow{9}{*}{ 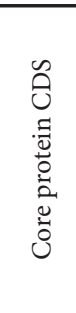 } & $\mathrm{A}$ & $\mathrm{NA}$ & ES & ES & ES & ES & ES & ES & ES & $5 \%$ \\
\hline & B & $S$ & $\mathrm{NA}$ & NS & VS & $S$ & ES & $S$ & ES & $18 \%$ \\
\hline & C & ES & VS & NA & ES & ES & ES & ES & ES & $2 \%$ \\
\hline & $\mathrm{D}$ & ES & ES & ES & NA & NS & ES & ES & ES & $5 \%$ \\
\hline & D (our study) & ES & ES & ES & NA & VS & ES & ES & ES & $12 \%$ \\
\hline & $\mathrm{E}$ & ES & ES & ES & ES & NA & ES & ES & ES & NA \\
\hline & $\mathrm{F}$ & ES & ES & ES & ES & ES & NA & ES & ES & $3 \%$ \\
\hline & G & ES & ES & ES & ES & ES & ES & NA & ES & $1 \%$ \\
\hline & $\mathrm{H}$ & ES & ES & ES & ES & ES & ES & ES & $\mathrm{NA}$ & $6 \%$ \\
\hline
\end{tabular}

${ }^{a}$ Reference HBV genotypes as predefined by the NCBI Genotyping resource [17].

b Difference between intragenotypic similarity scores of reference/clinical HBV genotypes (row headers) and intergenotypic similarity scores versus reference HBV genotypes (column headers) estimated in terms of unpaired Student's $t$ test $\mathrm{p}$ value, and considered extremely significant (ES; $\mathrm{p}<0.001$ ),

very significant $(\mathrm{VS} ; 0.001<\mathrm{p}<0.01)$, significant $(\mathrm{S} ; 0.01<\mathrm{p}<0.05)$, or not significant (NS; $p>0.05)$. NA = Nonapplicable.

${ }^{c}$ Variation of intragenotypic similarity scores of reference/clinical HBV genotypes (row headers) estimated in terms of RSD. Intragenotypic variation was not estimated for genotype $\mathrm{E}$ as only two reference sequences were predefined by NCBI. 


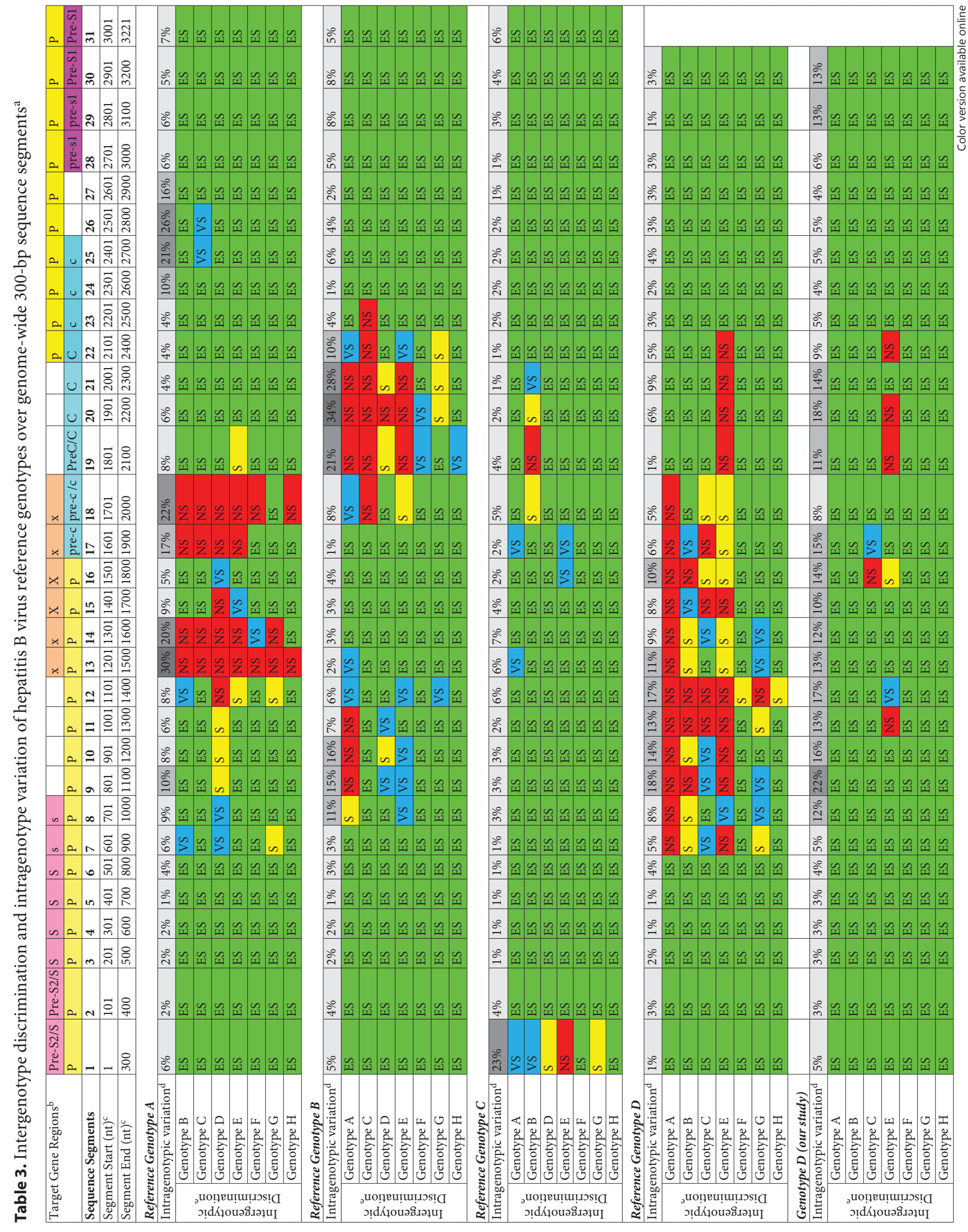




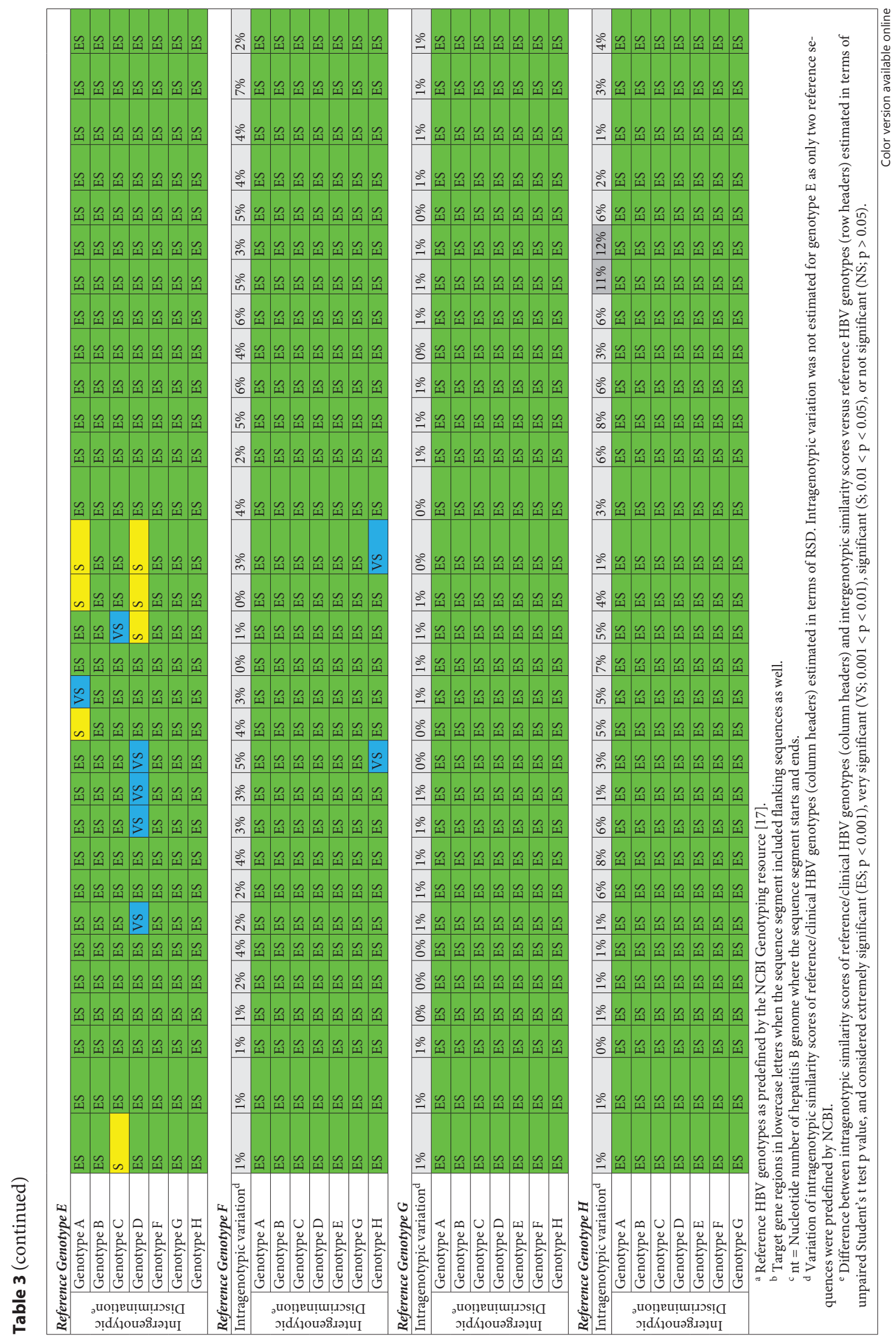




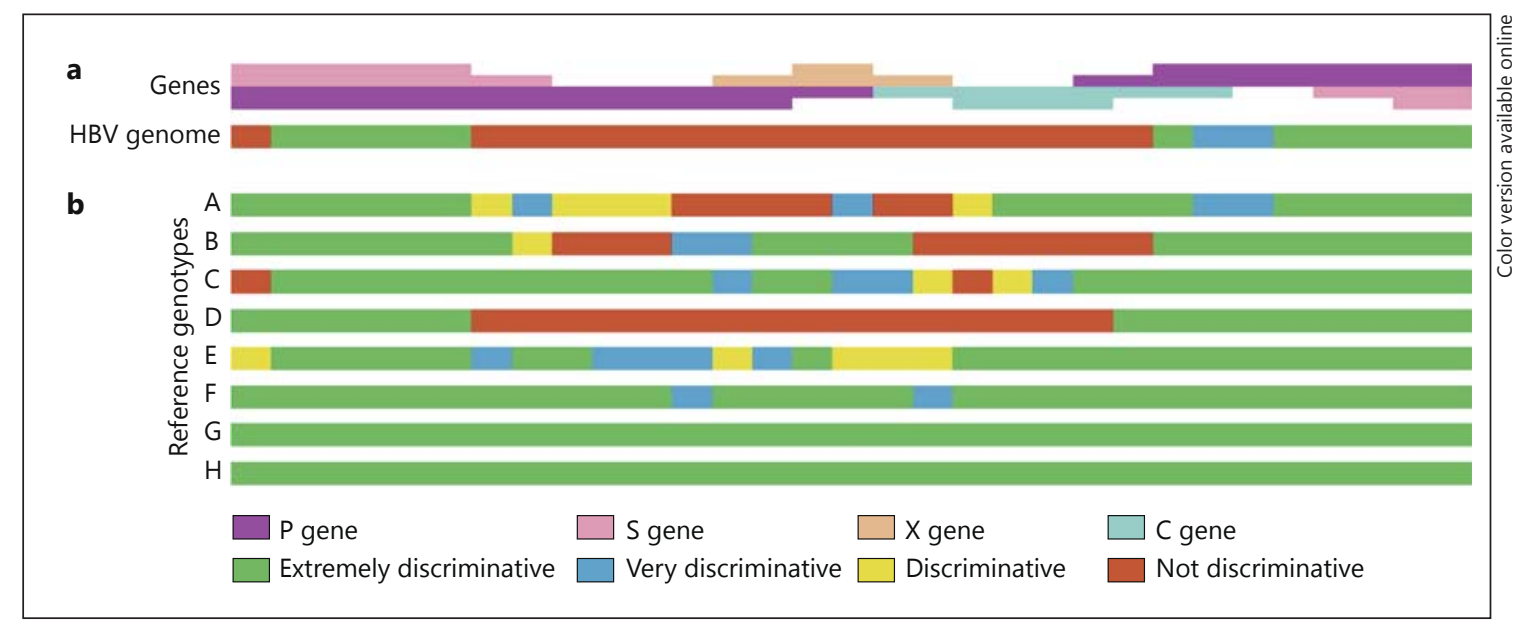

Fig. 2. Intergenotypic discriminatory capability of various 300-bp-long target gene regions over the entire sequence of HBV genome in general (a) and each HBV reference genotype (b). Target gene regions appear thinner when the sequence segment includes flanking sequences as well.

segments 15 and 16 of X gene CDS, segments 17 and 18 of X/C gene CDS, and segments 19-23 of C gene CDS showed either insignificant intergenotype discrimination of reference genotypes A, B, C and/or D, or different levels of intergenotype discrimination significance between various genotypes (table 3 ).

Intragenotypic similarity score RSD values of genomewide 300-bp sequence segments varied in the ranges of $1-30,1-34,1-7,1-18,0-7,0-1$ and $0-12 \%$ for the reference genotypes A, B, C, D, F, G and H, respectively. Student's $t$ test $p$ values corresponding to intergenotypic discriminatory capability and RSD values indicating intragenotypic variation showed a medium to strong positive correlation (average Pearson's correlation coefficients ranged between 0.4 and 0.8 ).

\section{Sequence Segment Analysis of Clinical Specimens}

Genotype D was assigned to all 70 complete HBV genome sequences of this study for matching its reference sequences with the highest similarity scores in most genome-wide segments. However, reference genotype $\mathrm{E}$ matched the query sequence segments $17-20$ of $X$ and $C$ gene CDS with either equal or higher similarity scores than those of reference genotype $\mathrm{D}$ in 65 of 70 query sequences.

Average intra- and intergenotypic similarity scores between query and reference sequences were extremely significantly different among most target regions except $\mathrm{X}$ gene CDS versus reference genotype $\mathrm{E}$ (table 2). Intergenotype discrimination was extremely significant over the 30 genome-wide 300-bp sequence segments except segment
11 of $\mathrm{P}$ gene sequence coding for the $\mathrm{C}$-terminal domain and segments 19, 20 and 22 of C gene CDS versus reference genotype $\mathrm{E}$, and segment 16 of $\mathrm{X}$ gene $\mathrm{CDS}$ versus reference genotype $\mathrm{C}$ (table 3 ). Intragenotypic variation was significantly higher in our study group than in the reference genotype D group for all studied target regions.

\section{Integrity of the Analyzed Genomes}

Among the 70 sequenced HBV genomes, 40 were 3,182-bp-long showing no deletions or insertions compared to the reference genotype $\mathrm{D}$ genomes. One- to 183-bp-long deletions in the pre-S, $\mathrm{X}$ and/or $\mathrm{C}$ regions and 2- to 9-bp-long insertions in $\mathrm{X}$ or $\mathrm{C}$ regions were found in 28 and 5 of 70 genomes, respectively. A premature stop codon in the precore region leading to an $\mathrm{HBeAg}$ negative genotype was found in 34 of 70 genomes. Furthermore, 8 of 28 deletion-mutant genomes contained premature stop codons in the $\mathrm{C}$ and/or S CDS probably causing nonviability. In addition, the start codons of large or middle $S$ were missing in 1 and 5 genomes, respectively.

\section{Discussion}

\section{Sequence Analysis of Reference Genotypes}

The NCBI Genotyping resource has collaboratively predefined a set of 23 complete reference genomes for all eight $\mathrm{HBV}$ genotypes, two to three sequences each, taking into account genetic polymorphisms and including both ancient and recent sequence data. A defined genotype is 
assigned to a query sequence when at least one of its reference sequences is matched with the highest similarity scores using BLAST pairwise alignments [16]. Hence, the lower the similarity scores versus the other reference genotypes are, the more decisive is the genotyping analysis and the more discriminative is the target gene region. This is the rationale upon which our study was designed and carried out. Accordingly, these predefined HBV reference sequences were compared intra- and intergenotypically to find out the most discriminative target gene regions.

Our revisiting approach revealed that sequencing either the complete genome or any entire CDS of the viral $\mathrm{P}$ and $\mathrm{S}$ genes (polymerase, large $\mathrm{S}$, middle $\mathrm{S}$ and $\mathrm{S}$ protein CDS as well as the entire pre-S region) can significantly differentiate all HBV genotypes. In contrast, genotypes B and/or D may be confounded with other genotypes by sequencing either $\mathrm{C}$ or $\mathrm{X}$ gene $\mathrm{CDS}$, respectively. Similarly, phylogenetic analysis delivered consistent but less detailed findings.

Our study was extended to further analyze the intergenotype discriminative capability of 31 genome-wide 300-bp sequence segments using the scored BLAST-dependent NCBI Genotyping tool, showing that thirteen segments over the CDS of S protein and polymerase $\mathrm{N}$ terminal domain were capable of discriminating all $\mathrm{HBV}$ genotypes significantly. Thus, any 300 -bp sequence segments chosen over nearly half the length of the genome are very suitable target gene regions to reliably assign any genotype to a query sequence (fig. 2). The findings point to the fact that it is the reliability of the target gene region that counts for intergenotypic discriminatory capability regardless of the sequence length.

Taking the geographical distribution of HBV genotypes into account, it may be required to identify only the dominant genotypes in a given geographic area for clinical purposes. In this context, HBV genotyping assays may be specifically designed for differentiating between genotypes $B$ and $C$ which predominate in China and Japan [1, $2,4,24]$, using even suboptimal target gene regions such as pre-S2 and X gene if considered necessary. Likewise, differentiating the globally distributed genotype $\mathrm{D}$ from non-D may be of interest worldwide $[2,6,10,11]$, and for this aim it is wise to use the optimal target gene regions. Obviously, the optimal target gene regions for HBV genotyping are genotype dependent.

Interestingly, intergenotypic discriminatory capability of studied target gene regions correlated negatively with intragenotype variation. Additionally, poor discrimination between various HBV genotypes was obviously attributed to the genotypes showing more intragenotype

Target Gene Regions for HBV

Genotyping variation such as genotypes $\mathrm{A}, \mathrm{B}$ and $\mathrm{D}$ and to a lower extent genotype $\mathrm{C}$ (table 3 ).

\section{Sequence Analysis of Clinical Specimens from Syria}

Genotype D was assigned to all tested clinical specimens based on both phylogenetic and scored BLAST analyses. However, equal or higher similarity scores in $\mathrm{X}$ and $\mathrm{C}$ genes versus reference genotype $\mathrm{E}$ by most query sequence contigs suggested an absence of significant differences in these gene regions between genotypes $\mathrm{D}$ and E. The lack of discrimination may be caused by the higher intragenomic variability in these genomic regions due to the high prevalence of HBeAg-negative variants in our cohort. These are associated with a tenfold higher mutation rate [25]. In fact, half of our patients had the precore stop mutant generating HBeAg negativity. Recombination with genotype E could be another possibility as reported elsewhere [26] but this is unlikely in our cohort because no genotype $\mathrm{E}$ infections were noted.

Poor discrimination from reference genotypes $\mathrm{E}$ and $\mathrm{C}$ appeared in miscellaneous sequence segments of polymerase C-terminal domain CDS as well as C and $\mathrm{X}$ gene regions. This finding was consistent with that of the reference genotype analysis above, though not on a par with it, which can be attributed to either (1) the extinguished effect of genetic variation due to managing a huge amount of data or (2) limited genetic variation of locally distributed genotype $\mathrm{D}$ variants that do not represent all subgenotypes of it. HBV subgenotypes were not explored in our study which could have explained such an observation. Moreover, our study may not represent all HBV strains circulating in the Syrian population since it was biased towards samples of high viral loads ( $>6 \log$ copies $/ \mathrm{ml}$ ), while the viral loads of most samples are supposedly lower [27].

In conclusion, we introduce a novel data evaluation approach applicable for the genotyping of other viruses as well, and a referential genome-wide tabulated guide of optimal target gene regions for HBV genotyping applications. It appears advisable to identify any of those 300-bp target sequences over the viral $\mathrm{S}$ protein and polymerase $\mathrm{N}$-terminal domain CDS which yield the best discrimination of all HBV genotypes. Further studies may reveal even shorter sequence segments of certain target gene regions capable of discriminating HBV genotypes significantly, but caution must be paid to potential recombination events that may occur genome-wide [28].

\section{Disclosure Statement}

The authors have no conflicts of interest to declare. 


\section{References}

>1 Zhao Y, Zhang XY, Hu Y, Zhang WL, Hu JL, Zeng AZ, Guo JJ, Huang WX, Chen WX, Shan YL, Huang AL: Comparison of a novel realtime PCR assay with sequence analysis, reverse hybridization, and multiplex PCR for hepatitis $\mathrm{B}$ virus type $\mathrm{B}$ and $\mathrm{C}$ genotyping. J Clin Microbiol 2011;49:3392-3394.

-2 Hannachi N, Fredj NB, Bahri O, Thibault V, Ferjani A, Gharbi J, Triki H, Boukadida J: Molecular analysis of HBV genotypes and subgenotypes in the Central-East region of Tunisia. Virol J 2010;7:302.

-3 Sitnik R, Paes Â, Mangueira CP, Pinho JRR: A real-time quantitative assay for hepatitis $B$ DNA virus (HBV) developed to detect all HBV genotypes. Rev Inst Med Trop Sao Paulo 2010;52:119-124.

4 Zhao Y, Zhang XY, Guo JJ, Zeng AZ, Hu JL, Huang WX, Shan YL, Huang AL: Simultaneous genotyping and quantification of hepatitis $\mathrm{B}$ virus for genotypes $\mathrm{B}$ and $\mathrm{C}$ by real-time PCR assay. J Clin Microbiol 2010;48:36903697.

$\checkmark 5$ Ali MM, Hasan F, Ahmad S, Al-Nakib W: Comparative evaluation of INNO-LiPA HBV assay, direct DNA sequencing and subtractive PCR-RFLP for genotyping of clinical HBV isolates. Virol J 2010;7:111.

6 Amini-Bavil-Olyaee S, Pourkarim MR, Schaefer S, Mahboudi F, Van Ranst M, Adeli A, Trautwein C, Tacke F: Single-step realtime PCR to quantify hepatitis B virus and distinguish genotype $\mathrm{D}$ from non-D genotypes. J Viral Hepat 2011;18:300-304.

$>7$ Stramer SL, Wend U, Candotti D, Foster GA, Hollinger FB, Dodd RY, Allain JP, Gerlich W: Nucleic acid testing to detect HBV infection in blood donors. N Engl J Med 2011;364:236247.

-8 Tadokoro K, Kobayashi M, Yamaguchi T, Suzuki F, Miyauchi S, Egashira T, Kumada H: Classification of hepatitis $\mathrm{B}$ virus genotypes by the PCR-Invader method with genotypespecific probes. J Virol Methods 2006;138: 30-39.

$>9$ Liu D, Shi M, Huang H, Long Z, Zhou X, Qin $\mathrm{J}$, Lin B: Isotachophoresis preconcentration integrated microfluidic chip for highly sensitive genotyping of the hepatitis $\mathrm{B}$ virus. J Chromatogr B Analyt Technol Biomed Life Sci 2006;844:32-38.
10 Ding L, Rui C, Zhansheng J, Xiangling W, Ping L, Zhen Y, Yanhai G, Ju Z: Detection of hepatitis $B$ virus genotypes A to D by the fluorescence polarization assay based on asymmetric PCR. J Virol Methods 2010;168:31-37.

$>11$ Liu WC, Lindh M, Buti M, Phiet PH, Mizokami M, Li HH, Sun KT, Young KC, Cheng PN, Wu IC, Chang TT: Genotyping of hepatitis B virus - genotypes A to $G$ by multiplex polymerase chain reaction. Intervirology 2008;51:247-252.

-12 Yang R, Cong X, Xu Z, Xu D, Huang W, Maertens R, Wei L: INNO-LiPA HBV genotyping is highly consistent with direct sequencing and sensitive in detecting $\mathrm{B} / \mathrm{C}$ mixed genotype infection in Chinese chronic hepatitis B patients and asymptomatic HBV carriers. Clin Chim Acta 2010;411:19511956.

13 Osiowy C, Giles E: Evaluation of the INNOLiPA HBV genotyping assay for determination of hepatitis B virus genotype. J Clin $\mathrm{Mi}$ crobiol 2003;41:5473-5477.

14 Weiss J, Wu H, Farrenkopf B, Schultz T, Song G, Shah S, Siegel J: Real time TaqMan PCR detection and quantitation of HBV genotypes A-G with the use of an internal quantitation standard. J Clin Virol 2004;30:86-93.

15 Yeh SH, Tsai CY, Kao JH, Liu CJ, Kuo TJ, Lin MW, Huang WL, Lu SF, Jih J, Chen DS, Chen PJ: Quantification and genotyping of hepatitis $B$ virus in a single reaction by real-time PCR and melting curve analysis. J Hepatol 2004;41: 659-666.

16 Rozanov M, Plikat U, Chappey C, Kochergin A, Tatusova T: A web-based genotyping resource for viral sequences. Nucleic Acids Res 2004;32:W654-659.

17 Chan HL, Tsui SK, Tse CH, Ng EY, Au TC, Yuen L, Bartholomeusz A, Leung KS, Lee KH, Locarnini S, Sung JJ: Epidemiological and virological characteristics of 2 subgroups of hepatitis B virus genotype C. J Infect Dis 2005; 191:2022-2032.
18 Kato H, Fujiwara K, Gish RG, Sakugawa H, Yoshizawa H, Sugauchi F, Orito E, Ueda R, Tanaka Y, Kato T, Miyakawa Y, Mizokami M: Classifying genotype $\mathrm{F}$ of hepatitis $\mathrm{B}$ virus into F1 and F2 subtypes. World J Gastroenterol 2005;11:6295-6304.

19 Larkin MA, Blackshields G, Brown NP, Chenna $\mathrm{R}$, McGettigan PA, McWilliam H, Valentin F, Wallace IM, Wilm A, Lopez R, Thompson JD, Gibson TJ, Higgins DG: Clustal W and Clustal $\mathrm{X}$ version 2.0. Bioinformatics 2007;23:2947-2948.

20 Goujon M, McWilliam H, Li W, Valentin F, Squizzato S, Paern J, Lopez R: A new bioinformatics analysis tools framework at EMBLEBI. Nucleic Acids Res 2010;38:W695-699.

21 Huelsenbeck JP, Ronquist F: MRBAYES: bayesian inference of phylogenetic trees. Bioinformatics 2001; 17:754-755.

22 Ronquist F, Huelsenbeck JP: MrBayes 3: bayesian phylogenetic inference under mixed models. Bioinformatics 2003;19:1572-1574.

23 Page RDM: TreeView: an application to display phylogenetic trees on personal computers. Comput Appl Biosci 1996;12:357-358.

24 Liu WC, Mizokami M, Buti M, Lindh M, Young KC, Sun KT, Chi YC, Li HH, Chang TT: Simultaneous quantification and genotyping of hepatitis B virus for genotypes A to $\mathrm{G}$ by real-time PCR and two-step melting curve analysis. J Clin Microbiol 2006;44: 4491-4497.

25 Bozkaya H, Ayola B, Lok AS: High rate of mutations in the hepatitis B core gene during the immune clearance phase of chronic hepatitis B virus infection. Hepatology 1996;24:32-37.

26 Bekondi C, Olinger CM, Boua N, Talarmin A, Muller CP, Le Faou A, Venard V: Central African Republic is part of the West-African hepatitis B virus genotype E crescent. J Clin Virol 2007;40:31-37.

27 El Chaar M, El Jisr T, Allain JP: Hepatitis B virus DNA splicing in Lebanese blood donors and genotype A to E strains: implications for hepatitis B virus DNA quantification and infectivity. J Clin Microbiol 2012;50:31593167.

-28 Zhou Y, Holmes EC: Bayesian estimates of the evolutionary rate and age of hepatitis B virus. J Mol Evol 2007;65:197-205. 